\title{
Nutritional requirements of meat-type and egg-type ducks: what do we know?
}

\author{
Ahmed Mohamed Fouad ${ }^{1,2}$, Dong Ruan ${ }^{1}$, Shuang Wang ${ }^{1}$, Wei Chen ${ }^{1}$, Weiguang Xia ${ }^{1}$ and Chuntian Zheng ${ }^{1 *}$
}

\begin{abstract}
The demand for duck meat, duck eggs, and associated products is increasing each year. Classic and modern selection programs have been applied to enhance the economic traits of ducks to satisfy the requirements of consumers and enhance the incomes of producers. The nutritional requirements of unselected ducks may not be adequate, however, to fulfill the potential productivity performance of modern birds, including both meat-type and egg-type ducks. In particular, an imbalanced diet is associated with low productive performance and signs of nutritional deficiency (if insufficient nutrients are supplied), as well as with high feed costs and manure problems that reflect flock health and welfare (if excessive nutrients are supplied). Thus, the main aim of this review is to summarize the results of previous studies that estimated the nutrient requirements of meat-type and egg-type ducks in order to evaluate current knowledge and to identify further issues that need to be addressed. In addition, the results obtained in previous studies are compared in order to understand how to lower commercial feed costs, fulfill the genetic potential of selected ducks, protect the environment from pollution, and satisfy the welfare and health needs of ducks.
\end{abstract}

Keywords: Ducks, Nutritional requirements

\section{Background}

Globally, the production of duck meat and eggs is increasing annually. Asia is the biggest producer of duck meat and eggs [1], and China is the main producer [2]. Genetic improvement programs for meat-type ducks have successfully enhanced their productive performance. In particular, Pekin ducks are well known as the main meat-type duck and they have been genetically enhanced to obtain a higher meat yield and lower rate of carcass fat deposition (lean meat) during $6 \mathrm{wk}$ to reach $3.2 \mathrm{~kg}$, whereas the unimproved type requires $11 \mathrm{wk}$ to reach only $1.7 \mathrm{~kg}[1,3,4]$. In addition, many studies have aimed to improve the main egg-type breed of ducks (Longyan laying ducks), important for several reasons, viz.: medium size (1.2$1.3 \mathrm{~kg}$ ), early maturation (110 d), high egg yield (more than 280 eggs/yr), huge populations (more than 300 million birds), adaptation to high ambient temperature,

\footnotetext{
*Correspondence: zhengcht@163.com

'Institute of Animal Science, Guangdong Academy of Agricultural Science, Key Laboratory of Animal Nutrition and Feed Science (South China) of Ministry of Agriculture, State Key Laboratory of Livestock and Poultry Breeding, Guangdong Public Laboratory of Animal Breeding and Nutrition, Guangdong Key Laboratory of Animal Breeding and Nutrition, Guangzhou, China

Full list of author information is available at the end of the article
}

and resistance to disease $[2,5,6]$. However, the recommendations of the National Research Council 1994 (NRC1994) [7] for approving the development of a new strain of meat-type ducks, however, defined their nutritional requirements based on 40-year-old data, or on results obtained in other species. Moreover, NRC1994 [7] did not define nutritional requirements for egg-type ducks. Thus, the present review summarizes the results obtained in recent studies of both meat-type and egg-type ducks in order to determine the current nutritional requirements of ducks, as well as to provide guidance for duck producers and duck feed manufacturers.

\section{Protein and energy}

Protein and energy are the first nutritional requirements that should be considered when formulating a diet because they represent the most expensive dietary components, but also because of their impact on the productive and reproductive performance of flocks for meat or egg production [8]. Fan et al. [9] determined the effects of the energy levels on performance and carcass quality in Pekin ducks from 2 to 6 wk of age. Their results showed that an energy level increase from 2,600 to 3,100 kcal of AME/ $\mathrm{kg}$ had a positive effect on the productive performance, but a 
negative effect on the carcass quality by increasing body fat deposition. Thus, based on the growth performance, they recommended 3,000 kcal of AME/ $\mathrm{kg}$ based on the growth performance when the diet contains $18 \%$ crude protein (CP). In addition, Xie et al. [10] suggested 2,900 $\mathrm{kcal}$ of AME/ $\mathrm{kg}$ with $20.5 \%$ $\mathrm{CP}$ for male White Pekin ducks during the first $3 \mathrm{wk}$ of age based on the growth performance and carcass quality when energy levels from 2,450 to 3,050 kcal of AME $/ \mathrm{kg}$ were tested. Wickramasuriya et al. [11] tested increasing energy levels $(2,600$ to $3,300 \mathrm{kcal}$ of $\mathrm{AME} / \mathrm{kg}$ ) and showed that native Korean ducks require 2,900 kcal of $\mathrm{AME} / \mathrm{kg}$ with $18 \mathrm{CP} \%$ from hatching to $21 \mathrm{~d}$ of age in order to maximize their productive performance and carcass weight. By contrast, few studies have aimed to estimate the energy and protein needs of laying ducks. However, Thongwittaya et al. [12] examined the impacts of the energy and protein levels on the performance of growing laying ducks (Khaki Campbell $\times$ Thai Native) and recommended 2,700 kcal of $\mathrm{AME} / \mathrm{kg}$ with $16.5 \% \mathrm{CP}$ from 18 to 37 wk of age. In China, the commercially formulated diet contains 2,500 kcal of $\mathrm{AME} / \mathrm{kg}$ and $17 \% \mathrm{CP}$ to satisfy the energy and protein requirements of egg-laying ducks.

\section{Amino acids}

Amino acids have essential roles in poultry nutrition due to their effects on performance, immunity, and meat and egg quality $[8,13]$. Methionine (Met) is the first main limiting amino acid in poultry nutrition. Thus, White Pekin ducks require $0.337 \%$ Met to obtain the highest average daily body weight gain, but this amount may be adjusted $0.339 \%$ to achieve the highest breast meat proportion according to Xie et al. [14] who estimated the Met requirements of white Pekin ducks from 3 to 7 wk of age. Elkin et al. [15] reported that the highest body weight gain in White Pekin ducklings during the first 2 wk of age required a diet containing $0.338 \%$ Met, while Xie et al. [16] found that diet formulations containing $0.481 \%$ Met maximized the growth performance in Pekin ducklings during the first $3 \mathrm{wk}$ of age. Zeng et al. [17] showed that White Pekin ducks, from 15 to $28 \mathrm{~d}$ of age, require diets containing $0.510,0.445$, and $0.404 \%$ Met to optimize their body weight gain, breast meat yield, and feather development, respectively, but for 15 to $35 \mathrm{~d}$ of age, these amounts were $0.468 \%$ Met to optimize the body weight gain, $0.408 \%$ Met for the breast meat yield, and $0.484 \%$ Met for feather development. In addition, Shaoxing laying ducks require $0.40 \%$ Met in their diet to maximize the egg production, egg weight, and feed conversion ratio (FCR) from 60 to 66 wk of age [18]. Fouad et al. [19] found that the egg weight, egg mass, and FCR were maximized in Longyan laying ducks from 19 to 47 wk of age by feeding a diet containing $0.41 \%$ Met.

Lysine (Lys) is the second limiting amino acid for poultry nutrition. In White Pekin ducks, Bons et al. [20] found that maximizing body weight gain required $1.06 \%$ Lys during the first 3 wk of age, for 3 to 7 wk of age, achieving the highest body weight gain, carcass yield, and breast yield required $1.02 \%$ Lys. Xie et al. [21] demonstrated that male White Pekin ducklings from 7 to $21 \mathrm{~d}$ of age, required $0.84,0.90$, and $0.98 \%$ Lys to achieve the highest body weight gain, feed efficiency, and breast meat proportion, respectively. Optimal body weight gain and feed efficiency were achieved with 0.71 and $1.01 \%$ Lys, respectively, in male Korean native ducklings from 1 to $21 \mathrm{~d}$ of age [22]. Optimizing the performance (egg production, egg weight, egg mass, and FCR) and eggshell quality in Longyan laying ducks, from 22 to 38 wk of age, requires feeding diets containing 0.80\% Lys [23].

The third limiting amino acid in poultry nutrition is threonine (Thr). Zhang et al. [24], conducted two experiments to estimate the Thr requirements of White Pekin ducks from 1 to $14 \mathrm{~d}$ of age and diets containing $0.86,0.92$, and $0.95 \% \mathrm{Thr}$ achieved the highest body weight gain, feed efficiency, and the maximal breast meat proportion. In addition, Xie et al. [25] recommended $0.67 \%$ Thr in the diets of White Pekin ducks from 1 to $21 \mathrm{~d}$ of age to maximize the body weight gain. Zhang et al. [26] suggested feeding White Pekin ducks, from 14 to $35 \mathrm{~d}$ of age, diets containing $0.75,0.74$, and $0.73 \% \mathrm{Thr}$ to achieve the standardized body weight gain, FCR, and relative breast meat yield (weight), respectively. In contrast, maximizing egg production, egg mass, and feed efficiency in Longyan laying ducks requires $0.57 \% \mathrm{Thr}$ in the diet from 17 to $45 \mathrm{wk}$ of age according to previous study in this laboratory [27].

Arginine (Arg) is not classified as a limiting amino acid but it is essential for poultry nutrition because avian species are incapable of its synthesis and it is also important as a precursor substrate for generating other molecules (e.g., nitric oxide, proteins, creatine, ornithine, glutamate, polyamines, proline, glutamine, and agmatine) with various physiological functions [28]. Wang et al. [29] found that in male White Pekin ducks from hatching to $21 \mathrm{~d}$ of age, the optimum body weight gain, FCR, and breast meat yield expressed as breast the weight relative to live body weight required $0.95,1.16$, and $0.99 \%$ Arg, respectively. Reproductive system development in Longyan laying ducks from 17 to $31 \mathrm{wk}$ of age requires feeding them diets containing 1.13\% Arg, but diets containing $1.46 \%$ Arg are recommended to obtain the best egg weight with highest eggshell quality [30]. 


\section{Minerals}

Calcium (Ca) in the form of calcium carbonate constitutes $96 \%$ of the eggshell, and almost $60-70 \%$ of the bone weight is $\mathrm{Ca}$ and $\mathrm{P}$ in the form of hydroxyapatite $[31,32]$. Therefore, providing inadequate amounts of $\mathrm{Ca}$, $\mathrm{P}$, and vitamin $\mathrm{D}$, as well as neglecting their optimal relative ratios in poultry diets will lead to productivity problems and economic losses. For example, Ca deficiency in laying ducks reduces the egg production rate, egg weight, eggshell thickness, eggshell breaking strength, and $\mathrm{Ca}$ deposition in the eggshell as a result of decreased $\mathrm{Ca}$ levels in the plasma and shell gland, as well as downregulating the expression of genes related to Ca transportation and eggshell biomineralization [33, 34]. In White Pekin and Mule ducks, Ca deficiency can lead to rickets, low growth rate, low feed utilization, and a high mortality rate [35, 36]. Xia et al. [37] estimated the $\mathrm{Ca}$ requirements of Longyan laying ducks, from 20 to $33 \mathrm{wk}$ of age, and recommended formulating diets containing $3.6 \% \mathrm{Ca}$ with $0.40 \%$ available $\mathrm{P}$ to maximize egg production, egg mass, feed utilization, and enhance the bone characteristics. In addition, $0.806 \% \mathrm{Ca}$ plus $0.403 \%$ non-phytate phosphorus and $0.796 \% \mathrm{Ca}$ plus $0.379 \%$ non-phytate phosphorus were recommended to attain the highest daily weight gain and lowest FCR, respectively, in White Pekin ducks during the first $3 \mathrm{wk}$ of age [38], whereas $0.72 \%$ Ca plus $0.37 \%$ non-phytate phosphorus were suggested to optimize daily weight gain from 3 to $6 \mathrm{wk}$ of age in White Pekin ducks [39].

Copper $(\mathrm{Cu})$ is a growth enhancer and antimicrobial as well as being a cofactor for many enzymes, e.g., cytochrome oxidase, lysyl oxidase, tyrosinase, phydroxyphenyl pyruvate hydrolase, dopamine beta hydroxylase, and copper-zinc superoxide dismutase [40]. Birds fed diets deficient in $\mathrm{Cu}$ may suffer from hypertriglyceridemia, hypercholesterolemia, anemia, feather depigmentation, abnormal bones, and poor growth [40]. Increasing the $\mathrm{Cu}$ level in the diets of laying birds can improve their performance (egg production and egg weight) and egg quality (lower percentage of abnormal eggs, i.e., soft and broken eggs), as well as reducing the total cholesterol, triglycerides, and low densitylipoprotein cholesterol levels, and increasing the high density-lipoprotein cholesterol levels in the blood [4144]. In addition, adding $\mathrm{Cu}$ to the diets of broiler chickens can improve the productive performance, breast meat yield, meat quality (juiciness), immunity, and the abundance of beneficial intestinal microflora (Lactobacillus and Bifidobacterium), as well as reducing the mortality rate and the abundance of harmful intestinal microflora (coliforms and Escherichia coli) [45, 46]. In male White Pekin ducks, Attia et al. [47] showed that improving the productive performance from hatching to $56 \mathrm{~d}$ of age required a diet containing $7 \mathrm{mg} \mathrm{Cu} / \mathrm{kg}$.
Shanma laying ducks, however, require diets containing $5 \mathrm{mg} \mathrm{Cu} / \mathrm{kg}$ from 17 to $45 \mathrm{wk}$ of age to fully express their genetic potential [48]. Meat-type ducks and eggtype ducks require low amounts of $\mathrm{Cu}$ in their diets compared with the requirements needed to reduce the cholesterol levels in their products. Thus, increasing the $\mathrm{Cu}$ concentration in the diets of male White Pekin ducks to $157 \mathrm{mg} / \mathrm{kg}$ reduced the cholesterol concentration in their meat [47]. Increasing the $\mathrm{Cu}$ concentration in the diet beyond $120 \mathrm{mg} / \mathrm{kg}$, however, leads to abnormal spleen, liver, and intestinal morphology in poultry [49].

Zinc $(\mathrm{Zn})$ is a unique mineral that is active in many enzymes, such as copper zinc superoxide dismutase (associated with the antioxidant defense system), carbonic anhydrase (associated with supplying carbonate ions during eggshell formation), and alkaline phosphatase (associated with bone structure and calcification), as well as in the regulation of lipids, protein metabolism, and sex hormones [50-53]. Hence, diets with inadequate Zn levels can inhibit egg production, fertility, hatchability, embryo development, hatched chicken availability, feather growth, and the development and proliferation of the immune organs, as well as increasing the incidence of leg problems, oxidative damage, and the mortality rate in poultry [54-58]. In contrast, the inclusion of $\mathrm{Zn}$ in the diet enhances eggshell quality by increasing carbonic anhydrase secretion during the late laying period in hens [57], as well as the immune response (humoral and cellular), resistance to disease $[59,60]$, bone structure by increasing calcium and phosphorus accumulation (which is reflected in bone strength) [61], growth rate, carcass yield, breast meat yield by promoting protein synthesis and suppressing protein degradation [52], and meat quality (color, water holding capacity, tenderness, and taste) in broiler chickens [53], and the egg yield, egg weight, fertility, hatchability, normal number of hatched chickens, and antioxidant capacity in broiler breeders [57]. Attia et al. [62] showed that in male White Pekin ducks, maximizing the body weight gain from 1 to $56 \mathrm{~d}$ requires diets

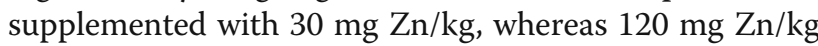
is needed to reduce body fat deposition and improve meat quality. However, $30 \mathrm{mg} \mathrm{Zn} / \mathrm{kg}$ in the diet is adequate for improving the performance of Longyan laying ducks during the peak laying period [63].

Manganese $(\mathrm{Mn})$ is an essential trace element in poultry nutrition because of its roles in normal bone and eggshell formation, enzyme functions, and nutrient (carbohydrate and lipid) metabolism [64]. Mn activates numerous enzymes such as hydrolases, transferases, kinases, lipoprotein lipase, hormonesensitive lipase, and mitochondrial superoxide dismutase $[65,66]$. An appropriate concentration of $\mathrm{Mn}$ is required in poultry diets to support the endocrine system $[67,68]$, 
immune system [69], antioxidant defense system [70], bone development [71], and eggshell structure and strength [72], as well as maximizing hatchability and minimizing embryo death rate [73], while it is also beneficial for regulating body fat deposition and improving meat quality [8]. A Mn-deficient diet leads to different types of perosis, inhibits bone development, decreases egg yield, and increases the amount of eggs with poor eggshell formation [74, 75]. According to a previous study from this laboratory [76], Shanma laying ducks require diets containing $90 \mathrm{mg} \mathrm{Mn} / \mathrm{kg}$ from 17 to $36 \mathrm{wk}$ of age in order to optimize their antioxidant defense system.

Iron $(\mathrm{Fe})$ is required to produce hemoglobin and to activate several enzymes, such as succinate dehydrogenase, catalase, and cytochrome c oxidase [77]. Insufficient Fe in the diet can impair body weight gains, feed consumption, FCR, and elevate mortality in broiler chickens [78], as well as reducing egg production, egg weight, and fertility rates in broiler and quail breeders $[79,80]$. Dietary supplementation with Fe can increase growth rate, thymus weight, activity of antioxidant enzymes [81], and cell-mediated responses in broilers [82]. In Shanma laying ducks, Xia et al. [83] showed that 52.2, 97.2, and $127.2 \mathrm{mg} \mathrm{Fe} / \mathrm{kg}$ are required to maintain performance, improve the yolk color, and enhance hemoglobin and hematocrit levels, respectively.

Selenium (Se) is a component of the enzyme glutathione peroxidase and it is required to produce type 1 iodothyronine deiodinase, which is needed in the thyroid gland to synthesize the active hormone triiodothyronine $\left(\mathrm{T}_{3}\right)$ [84]. Se-deficient diets are associated with inhibited immune organ development (spleen, thymus, and bursa) [85-87], induction of oxidative injury in the liver, kidney, and pancreas (thereby affecting their vital functions) [88-90], as well as reductions in egg production, egg weight, hatchability [91], body weight gain, and feather growth [92]. By contrast, diets containing adequate levels of Se improve the egg yield, egg weight, antioxidant capacity [93, 94], meat quality (juiciness), feather growth [95], immune system defense [96], semen quality (motility and lifetime sperm number are increased, whereas the numbers of dead and abnormal sperm are decreased), fertility, and hatchability [97]. From 1 to $49 \mathrm{~d}$ of age, Cherry Valley hybrid ducks need $0.4 \mathrm{mg} \mathrm{Se} / \mathrm{kg}$ to improve their growth rate [98]. In addition, Shanma laying ducks require 0.18 and $0.24 \mathrm{mg} \mathrm{Se} / \mathrm{kg}$ of diet for egg production in the early and peak-laying phases, respectively, whereas $0.38 \mathrm{mg}$ $\mathrm{Se} / \mathrm{kg}$ of diet is recommended to enhance the activity of the glutathione redox system [99]. Moreover, from hatching to $3 \mathrm{wk}$ of age, White Pekin ducks require
$0.236 \mathrm{mg} \mathrm{Se} / \mathrm{kg}$ of diet to protect their tissues against oxidative damage [100].

\section{Water-soluble vitamins}

Choline is a crucial nutrient for poultry because of its role in lipid metabolism and liver functions [101]. In avian species, perosis, fatty liver syndrome, and inhibition of growth rate are induced when a diet that is deficient in choline is fed [102-104]. Thus, Lein and Jan [105] fed Tsaiya laying ducks diets supplemented with choline to investigate its effects on egg production and fatty liver syndrome. They found that adding $2,136 \mathrm{mg} /$ $\mathrm{kg}$ of diet for only $4 \mathrm{wk}$ during the peak laying period improved egg production and reduced fat accumulation in the liver. However, Ma et al. [106] found no improvement in the laying rate of Shaoxing laying ducks when fed diets supplemented with choline during their peak laying period for $20 \mathrm{wk}$, but fat deposition in the liver and the cholesterol content of eggs were reduced by adding 500 and $750 \mathrm{mg}$ choline/kg of diet, respectively, although no explanation was provided for the reduction in egg cholesterol. In meat-type ducks (White Pekin ducks), Wen et al. $[103,104]$ found that diets containing 778,810 , and $1,182 \mathrm{mg}$ choline $/ \mathrm{kg}$ were sufficient to enhance phospholipid synthesis, improve growth rate, and prevent perosis during the first 3 wk of age, respectively, while diets containing 779 and $980 \mathrm{mg}$ choline/ $\mathrm{kg}$ were required to enhance phospholipid production and maximize the average daily weight gain from 21 to $42 \mathrm{~d}$ of age.

Riboflavin or vitamin $B_{2}$ is an essential vitamin for completion of the glutathione redox cycle and generating reduced glutathione, which protect cells against oxidative damage due to its role as an endogenous antioxidant [107]. In meat-type birds, diets deficient in riboflavin can lead to growth rate retardation, leg problems, an imbalanced antioxidant defense system, low carcass yield, low meat quality, and a high mortality rate [108-112], whereas in egg-type birds, it can reduce the rates of egg production, egg weight, and hatchability [113, 114]. Tang et al. [110] demonstrated that from 1 to $21 \mathrm{~d}$ of age, male White Pekin ducks required diets containing 3.31 and $5.20 \mathrm{mg}$ riboflavin $/ \mathrm{kg}$ to achieve the highest daily weight gain and feed utilization rate, respectively, based on corn-corn gluten meal diets, but the amounts required were 3.27 and $3.33 \mathrm{mg}$ riboflavin/ $\mathrm{kg}$ of diet in female White Pekin ducks. In addition, male White Pekin ducks fed corn-soybean meal diets during the first $3 \mathrm{wk}$ of age only required diets containing 3.01 and $2.79 \mathrm{mg}$ riboflavin $/ \mathrm{kg}$ to achieve the optimum body weight gain and FCR, respectively [111]. Similar to sex, age also affects the riboflavin requirements, where Tang et al. [112] recommended diets containing 2.43 and $2.31 \mathrm{mg}$ riboflavin $/ \mathrm{kg}$ for the optimum body weight gain and FCR, respectively, in male White 
Pekin ducks aged 15 to $35 \mathrm{~d}$. Wang et al. [115] reported that diets containing1.32 $\mathrm{mg}$ riboflavin $/ \mathrm{kg}$ satisfied the requirements for egg production, egg weight, egg mass, and FCR in Longyan laying ducks from 22 to 34 wk of age, but enhancing the Haugh unit required a diet containing $7.32 \mathrm{mg}$ riboflavin.

Biotin is a coenzyme that has fundamental roles in carbohydrate, protein, and lipid metabolism [116]. Diets containing inadequate amounts of biotin can lead to fatty liver and kidney syndrome, a low hatchability rate, low growth rate, and the increased occurrence of foot pad dermatitis in birds [114-119]. Thus, injecting biotin into fertilized eggs, adding biotin to drinking water, or supplementing the diet with biotin can improve egg production, fertility, hatchability, and body weight gains, as well as decreasing the footpad burn score and hock burn score [120-123]. Zhu et al. [119] reported that diets containing $0.180 \mathrm{mg}$ biotin $/ \mathrm{kg}$ satisfy the productive performance requirements for male White Pekin ducks during the first $4 \mathrm{wk}$ of age, but dietary supplementation with $0.21 \mathrm{mg}$ biotin $/ \mathrm{kg}$ is needed to minimize the number of birds suffering from foot pad dermatitis.

Folic acid is necessary for maintaining a normal growth rate and acceptable FCR in broiler chickens, as well as a greater egg weight and higher hatchability in egg-type birds [124, 125]. The egg weight and egg mass in laying hens aged 24 wk can be improved by adding $4 \mathrm{mg}$ folic acid/kg of diet for $8 \mathrm{wk}$ [126]. Dietary folic acid supplementation alleviates the oxidative stress induced by heat stress and improves the productive performance and carcass yield in quails [127]. Increasing the folic acid content in the diets of laying hens leads to the production of eggs that are rich in folate, which is essential for preventing many diseases in human [128]. Recently, Liu et al. [129] implicated folic acid as having a role in embryo development in broiler chickens. Moreover, $\mathrm{Li}$ et al. [130] found that supplementation with $150 \mu \mathrm{g}$ folic acid in ovo enhanced the hatchability, growth performance, antibody production (IgG and IgM), and secretion of cytokines (IL-2 and IL-4) in broiler chickens. In ducks, Xia et al. [131] showed that feeding Shanma laying ducks a corn-soybean meal could meet their folic acid requirements in terms of performance from 18 to $32 \mathrm{wk}$ of age, but the addition of $1.0 \mathrm{mg}$ folic acid/kg to their diet was required to improve the eggshell percentage.

Pyridoxine or vitamin $\mathrm{B}_{6}$ deficiency inhibit feed consumption as well as promoting catabolism and retarded the growth of organs, including the comb, wattle, ovary, and veins, thereby leading to decreases in egg production, egg weight, fertility, and hatchability, as well as impaired feather growth in the offspring of mature birds [132, 133]. In broiler chickens, pyridoxine deficiency causes a high mortality rate, low body weight gain, low antibody production, and bone structure alterations, thereby leading to an increased occurrence of leg problems in flocks $[134,135]$. Injecting pyridoxine into fertilized turkey eggs improves their hatchability [136]. Supplementing the diets of laying hens with $8.0 \mathrm{mg}$ pyridoxine/kg improves egg production and the FCR [137]. Moreover, during the first $4 \mathrm{wk}$ of age, White Pekin ducks require $2.44 \mathrm{mg}$ pyridoxine to improve their growth performance [138].

Niacin or nicotinic acid is a precursor required for the biosynthesis of the coenzymes nicotinamide adenine dinucleotide and nicotinamide adenine dinucleotide phosphate, and thus it plays a fundamental role in metabolism [139]. Niacin deficiency is linked to reductions in the growth rate and feather growth, and an increased incidence of leg problems in meat-type birds [140, 141], as well as poor eggshell quality, low egg production, and decreased hatchability in egg-type birds [142]. The addition of $60 \mathrm{mg}$ niacin to a corn-soybean meal diet is recommended for improving body weight gains, the meat yield, and meat quality in broiler chickens [143]. In laying hens, egg production, FCR, and eggshell quality can be improved by increasing the niacin levels [144]. In male White Pekin ducks, Xie et al. [145] found that feeding diets containing $40 \mathrm{mg}$ niacin/ $\mathrm{kg}$ from hatching until $21 \mathrm{~d}$ of age achieved satisfactory performance and reduced the incidence of bowed leg deformities. Wang et al. [146] recommended diets containing $90 \mathrm{mg}$ niacin $/ \mathrm{kg}$ to improve the eggshell quality in Longyan laying ducks during the early laying period.

Thiamine or vitamin $B_{1}$ acts as a co-enzyme that participates in the oxidative decarboxylation of pyruvic acid and $\alpha$-ketoglutaric acid, thereby leading to the production acetyl-coenzyme A (CoA) and succinyl-CoA, which are involved in the metabolism of carbohydrates, proteins, and lipids [116]. Feeding poultry a diet deficient in thiamine leads to reductions in appetite, growth, carcass yield, and hatchability, as well impaired carbohydrate metabolism and a high mortality rate [147-150]. A previous study in this laboratory showed that the performance of Longyan laying ducks aged 22 to 42 wk can be maximized by providing a diet containing $1.55 \mathrm{mg}$ thiamine/ $\mathrm{kg}$ [unpublished data].

\section{Fat-soluble vitamins}

Vitamin A or retinol is essential for embryonic development, growth, reproduction, and function of the immune system. Vitamin A deficiencies lead to defects in the nervous system of embryos as well as reducing the growth rate, egg production, antibody production, and hatchability [151-154]. In broilers and broiler breeders, Yuan et al. [155], Fan et al. [156], and Chen et al. [157] showed that adequate levels of vitamin A can optimize the rates of antibody production, egg production, 
egg quality, and hatchability. Wei et al. [158] demonstrated that a diet containing 2,500 IU vitamin $\mathrm{A} / \mathrm{kg}$ improved the productive performance in White Pekin ducks from hatching to $21 \mathrm{~d}$ of age. Wang et al. [159] found that a corn-soybean meal diet could satisfy the vitamin A requirements needed for performance and egg quality in Longyang laying ducks from 20 to 36 wk of age, but the addition of $400 \mathrm{IU}$ vitamin A improved the antioxidant defense system.

Vitamin D and its active forms (25-hydroxycholecalciferol and $1 \alpha$-hydroxycholecalciferol) affect bone development and eggshell quality because of their roles in the calcium and phosphorus cycles, but these are not their only functions in poultry. Stadelman et al. [160] reported that vitamin $\mathrm{D}$ deficiency reduced hatchability in breeders and the growth rate of their offspring. Aslam et al. [161] demonstrated that vitamin $\mathrm{D}$ deficiency retarded the growth of immune organs, and lowered the counts of macrophages and decreased their capacity for phagocytosis. Supplementation with vitamin $\mathrm{D}_{3}$ or it active forms improves the productive performance, breast meat yield, meat quality (by enhancing the skin and meat color, juiciness and tenderness) [162-164], immune system defense [165, 166], egg production, egg weight, and hatchability [167]. Wang et al. [168] showed that diets containing $1,000 \mathrm{IU}$ vitamin $\mathrm{D}_{3} / \mathrm{kg}$ are sufficient to meet the needs of White Pekin ducks during the first 2 wk of age. In egg-laying ducks, Xie and Wang [169] showed that diets containing 550 IU vitamin D/kg are sufficient for Jinding ducks from hatching until $4 \mathrm{wk}$ of age based on improvements in the relative weights of the immune organs and the suppression of lipid peroxidation. In an experiment from 16 to $18 \mathrm{wk}$ of age, the rates of egg production, egg weight, FCR, and egg quality were not changed by dietary supplementation of vitamin $\mathrm{D}_{3}$ in Longyan laying ducks, but adequate bone mineralization required a diet containing $800 \mathrm{IU} / \mathrm{kg}$ [170]. Chen [171] found that optimized egg production and enhancing eggshell quality required diets containing vitamin $\mathrm{D}_{3}$ at 1,069 and $989 \mathrm{IU} / \mathrm{kg}$, respectively, in Tsaiya egg-ducks from 30 to $50 \mathrm{wk}$ of age.

Vitamin E protects cell membranes against damage by free radicals due to its antioxidant properties. Vitamin $\mathrm{E}$ is linked to the economic traits of poultry, including fertility, hatchability, immunity, and meat and egg quality. Vitamin E deficiency impairs egg production, fertility, and hatchability [172], suppresses development of immune organs [173], and leads to the occurrence of muscular dystrophy in breast muscles [174]. Thus, dietary supplementation with vitamin $\mathrm{E}$ enhances egg production, egg quality, fertility, semen quality (improved viability, motility, and concentration, and a reduced percentage of dead and abnormal sperm) [175-177], humoral and cell-mediated immune responses [178], meat quality by reducing drip losses and enhancing tenderness, and intramuscular fat [179]. Despite the importance of vitamin E for poultry nutrition, only one study has investigated the influence of dietary vitamin $\mathrm{E}$ supplementation on the performance of Tsaiya laying ducks [180]. In this study, Chen and Hsu [180] recommended dietary supplementation with $400 \mathrm{mg} \alpha$ tocopherol/kg to enhance egg production, egg mass, and FCR in Tsaiya laying ducks from 30 to $36 \mathrm{wk}$ of age.

\section{Conclusions}

Clearly, nutritional deficiencies can directly affect the productive performance of poultry, including ducks. The symptoms of nutritional deficiencies sometimes interact with each other, which can lead to difficulties

Table 1 Nutritional requirements of meat-type (White Pekin ducks) and egg-type ducks (Longyan ducks) in commercial production

\begin{tabular}{|c|c|c|c|}
\hline Nutrient & $1-21 d$ & $22-42 d$ & Laying period \\
\hline Metabolizable energy, kcal/kg & 2,900 & 3,000 & 2,500 \\
\hline Protein, \% & 20 & 18 & 17 \\
\hline Methionine, \% & $0.48-0.50$ & $0.47-0.50$ & 0.40 \\
\hline Lysine, \% & 1.1 & 1.0 & 0.80 \\
\hline Threonine, \% & $0.70-0.80$ & $0.70-0.80$ & 0.60 \\
\hline Tryptophan, \% & 0.23 & 0.23 & 0.21 \\
\hline Calcium, \% & 0.83 & 0.89 & 3.60 \\
\hline Available phosphorus, \% & 0.40 & 0.40 & 0.35 \\
\hline Manganese, mg/kg & $80-100$ & $80-100$ & 90 \\
\hline Zinc, mg/kg & 60 & 60 & 90 \\
\hline Iron, mg/kg & 60 & 60 & 50 \\
\hline Copper, mg/kg & 10 & 10 & 10 \\
\hline lodine, mg/kg & 0.2 & 0.2 & 0.50 \\
\hline Selenium, mg/kg & 0.3 & 0.3 & 0.40 \\
\hline Vitamin A, IU & 10,000 & 8,000 & 12,000 \\
\hline Vitamin $D_{3}, I U$ & 3,000 & 3,000 & 2,000 \\
\hline Vitamin $\mathrm{E}, \mathrm{mg} / \mathrm{kg}$ & 20.0 & 20.0 & 38.0 \\
\hline Vitamin $\mathrm{K}, \mathrm{mg} / \mathrm{kg}$ & 2.0 & 2.0 & 1.0 \\
\hline Thiamine, Vitamin $B_{1}, \mathrm{mg} / \mathrm{kg}$ & 2.0 & 2.0 & 3.0 \\
\hline Riboflavin, Vitamin $B_{2}, \mathrm{mg} / \mathrm{kg}$ & 10.0 & 8.0 & 9.6 \\
\hline Pyridoxine, Vitamin $B_{6}, \mathrm{mg} / \mathrm{kg}$ & 4.0 & 4.0 & 6.0 \\
\hline $\begin{array}{l}\text { Cyanocobalamin, Vitamin } B_{12} \\
\mathrm{mg} / \mathrm{kg}\end{array}$ & 0.02 & 0.02 & 0.03 \\
\hline Choline, mg/kg & 1,000 & 750 & 500 \\
\hline Pantothenic acid, mg/kg & 20.0 & 10.0 & 28.5 \\
\hline Folic acid, mg/kg & 1.0 & 1.0 & 0.6 \\
\hline Biotin, mg/kg & 0.2 & 0.2 & 0.15 \\
\hline Niacin, mg/kg & 50.0 & 50.0 & 25.0 \\
\hline
\end{tabular}




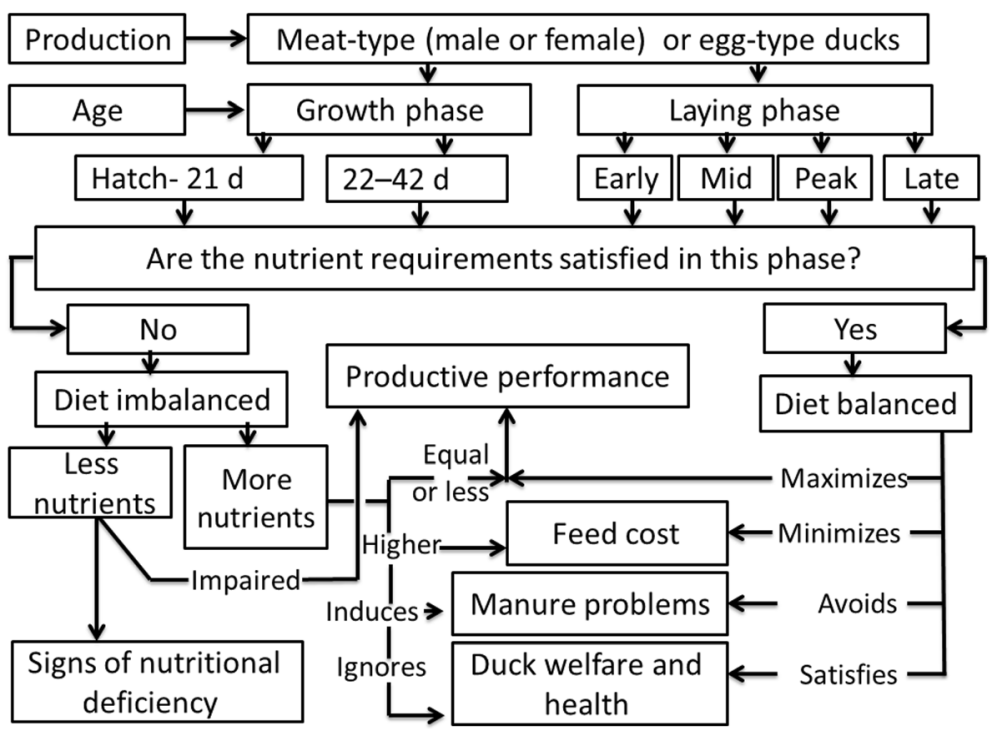

Fig. 1 Impacts of nutritional requirements on productive performance, feed cost, manure problems, and duck welfare and health

interpreting these symptoms. However, it is not always advisable to simply increase the nutrient levels in the diet because increasing these levels may waste money and lead to losses via manure. Thus, simply increasing the amounts of proteins, amino acids, $\mathrm{Ca}, \mathrm{P}$, and other nutrients to meet the requirements of animals is not recommended because there is a lack of information and suitable studies regarding the optimal levels of these nutrients. Thus, uninformed dietary supplementation with nutrients may affect the welfare and health of animals, and increase environmental pollution. Therefore, based on the previous studies discussed above as well as the nutrient levels used in commercial feed for White Pekin ducks and Longyan laying ducks (Table 1) (the most studied strains of ducks) and considering age and gender (only in meat-type ducks), as shown in Fig. 1, it is possible to revise and modify the commercial nutritional requirements for ducks. Thus, the current situation can be evaluated and further experiments may be designed to identify the optimal requirements for duck production. This information may facilitate improvements to industrial duck production by considering duck welfare and health, as well protecting the environment from contamination with excess nutrients.

\section{Abbreviations}

AME: Apparent metabolizable energy; Ca: Calcium; CP: Crude protein; Cu: Copper; Fe: Iron; Se: Selenium; Mn: Manganese; NRC: National research council; P: Phosphorus; Zn: Zinc

\section{Funding}

Work in our laboratory was supported by the Fund for China Agricultural Research System (CARS-42-13), the Science and Technology Program of Guangdong Province (2011A020102009 and 2016A020210043) and Operating Funds for Guangdong Provincial Key Laboratory of Animal Breeding and Nutrition (2014B030301054). The funders had no role in preparation of the manuscript or decision to publish.

\section{Availability of data and materials} Not applicable.

\section{Authors' contributions}

CZ conceived this project. AMF wrote the manuscript. AMF, DR, SW, WC and $W X$ contributed to the discussion. CZ had the primary responsibility for the content of the paper. All authors read and approved the final manuscript.

Ethics approval and consent to participate

Not applicable. This article reviews published studies and does not require the approval of animal use or consent to participate.

Consent for publication

Not applicable.

\section{Competing interests}

None of the authors have any competing interests in the manuscript.

\section{Author details}

${ }^{1}$ Institute of Animal Science, Guangdong Academy of Agricultural Science, Key Laboratory of Animal Nutrition and Feed Science (South China) of Ministry of Agriculture, State Key Laboratory of Livestock and Poultry Breeding, Guangdong Public Laboratory of Animal Breeding and Nutrition, Guangdong Key Laboratory of Animal Breeding and Nutrition, Guangzhou, China. ${ }^{2}$ Department of Animal Production, Faculty of Agriculture, Cairo University, Giza, Egypt. 
Received: 10 April 2017 Accepted: 13 December 2017 Published online: 16 January 2018

\section{References}

1. Huang JF, Pingel H, Guy G, Łukaszewicz E, Baéza E, Wang SD. A century of progress in waterfowl production, and a history of the WPSA waterfowl working group. World's Poult Sci J. 2012;68:551-63.

2. Zeng T, Chen L, Du X, Lai SJ, Huang SP, Liu YL, et al. Association analysis between feed efficiency studies and expression of hypothalamic neuropeptide genes in laying ducks. Anim Genet. 2016;47: 606-9.

3. Xu T, Gu L, Schachtschneider KM, Liu X, Huang W, Xie M, et al. Identification of differentially expressed genes in breast muscle and skin fat of postnatal Pekin duck. PLoS One. 2014;9:e107574.

4. Wang X, Fang C, He J, Dai Q, Fang R. Comparison of the meat metabolite composition of Linwu and Pekin ducks using $600 \mathrm{MHz} 1 \mathrm{H}$ nuclear magnetic resonance spectroscopy. Poult Sci. 2017;96:192-9.

5. Lin RL, Chen HP, Rouvier R, Marie-Etancelin C. Genetic parameters of body weight, egg production, and shell quality traits in the Shan ma laying duck (Anas platyrhynchos). Poult Sci. 2016;95:2514-9.

6. Zhu ZM, Miao ZW, Chen HP, Xin QW, Li L, Lin RL, et al. Ovarian transcriptomic analysis of Shanma ducks at peak and late stages of egg production. Asian-Aust J Anim Sci. 2017;30(9):1215-24. https://doi.org/10 5713/ajas.16.0470.

7. National Research Council. Nutrient requirements of poultry. $9^{\text {th }}$ ed. Washington, DC: National Academy Press; 1994.

8. Fouad AM, El-Senousey HK. Nutritional factors affecting abdominal fat deposition in poultry: a review. Asian-Aust J Anim Sci. 2014:27:1057-68.

9. Fan HP, Xie M, Wang WW, Hou SS, Huang W. Effects of dietary energy on growth performance and carcass quality of white growing Pekin ducks from two to six weeks of age. Poult Sci. 2008;87:1162-4.

10. Xie M, Zhao JN, Hou SS, Huang W. The apparent metabolizable energy requirement of white Pekin ducklings from hatch to 3 weeks of age. Anim Feed Sci Technol. 2010;157:95-8.

11. Wickramasuriya SS, Yoo J, Kim JC, Heo JM. The apparent metabolizable energy requirement of male Korean native ducklings from hatch to 21 days of age. Poult Sci. 2016:95:77-83.

12. Thongwittaya N, Pleusamran $\mathrm{P}$, Choktaworn N, Tasaki I. Energy and protein requirements of khaki Campbell $x$ Thai native growing ducks. Asian-Aust. J Anim Sci. 1992;5:357-63.

13. Kidd MT. Nutritional modulation of immune function in broilers. Poult Sci. 2004:83:650-7.

14. Xie M, Hou SS, Huang W. Methionine requirements of male white Peking ducks from twenty-one to forty-nine days of age. Poult Sci. 2006;85:743-6.

15. Elkin RG, Stewart TS, Rogler JC. Methionine requirement of male white Pekin ducklings. Poult Sci. 1986;65:1771-6.

16. Xie M, Hou SS, Huang W, Zhao L, JY Y, Li WY, et al. Interrelationship between methionine and cystine of early Peking ducklings. Poult Sci. 2004;83:1703-8

17. Zeng QF, Zhang Q, Chen X, Doster A, Murdoch R, Makagon M, et al. Effect of dietary methionine content on growth performance, carcass traits, and feather growth of Pekin duck from 15 to 35 days of age. Poult Sci. 2015;94:1592-9.

18. He JH, Li JB, Gao FX, Liu QH, Shu JC, Liu DJ. Dietary methionine requirement of the Chinese egg-laying duck. Br Poult Sci. 2003;44:741-5.

19. Fouad AM, Ruan D, Lin YC, Zheng CT, Zhang HX, Chen W, et al. Effects of dietary methionine on performance, egg quality and glutathione redox system in egg-laying ducks. Br Poult Sci. 2016;57:818-23.

20. Bons $A$, Timmler $R$, Jeroch $H$. Lysine requirement of growing male Pekin ducks. Br Poult Sci. 2002;43:677-86.

21. Xie M, Guo Y, Zhang T, Hou S, Huang W. Lysine requirement of male white pekin ducklings from seven to twenty-one days of age. Asian-Aust. J Anim Sci. 2009:22:1386-90

22. Wickramasuriya SS, Yi YJ, Yoo J, Kim JC, Heo KN, Heo JM. Lysine requirements of Korean native ducklings for three weeks after hatch. J Appl Poult Res. 2016;25:464-73.

23. Fouad AM, Chen W, Ruan D, Shuan W, Weiguan X, Zheng CT. Effects of dietary lysine supplementation on performance, egg quality and development of reproductive system in egg-laying ducks. J Appl Anim Res. 2017; https://doi.org/10.1080/09712119.2017.1308868.
24. Zhang Q, Zeng QF, Cotter P, Applegate TJ. Dietary threonine response of Pekin ducks from hatch to $14 \mathrm{~d}$ of age based on performance, serology, and intestinal mucin secretion. Poultry Sci. 2016;95:1348-55.

25. Xie M, Zhang L, Wen ZG, Tang J, Huang W, Hou SS. Threonine requirement of white Pekin ducks from hatch to $21 \mathrm{~d}$ of age. Br Poult Sci. 2014;55:553-7.

26. Zhang Q, Xu L, Doster A, Murdoch R, Cotter P, Gardner A, et al. Dietary threonine requirement of Pekin ducks from 15 to 35 days of age based on performance, yield, serum natural antibodies, and intestinal mucin secretion. Poult Sci. 2014;93:1972-80

27. Fouad AM, Zhang HX, Chen W, Xia WG, Ruan D, Wang S, et al. Estimation of L-threonine requirements for Longyan laying ducks. Asian-Aust. J Anim Sci. 2017;30:206-10.

28. Fouad AM, El-Senousey HK, Yang XJ, Yao JH. Role of dietary l-arginine in poultry production. Int J Poult Sci. 2012;11:718-29.

29. Wang C, Xie M, Huang W, Xie JJ, Tang J, Hou SS. Arginine requirements of white Pekin ducks from 1 to 21 days of age. Poult Sci. 2013:92:1007-10.

30. Xia W, Fouad AM, Chen W, Ruan D, Wang S, Fan Q, et al. Estimation of dietary arginine requirements for Longyan laying ducks. Poult Sci. 2017; 96:144-50.

31. Rath NC, Huff GR, Huff WE, Balog JM. Factors regulating bone maturity and strength in poultry. Poult Sci. 2000;79:1024-32.

32. Hincke MT, Nys Y, Gautron J, Mann K, Rodriguez-Navarro AB, McKee MD. The eggshell: structure, composition and mineralization. Front Biosci. 2012; 17:1266-80

33. Chen WL, Shen TF. Comparative studies on the utilization of calcium between laying Tsaiya duck and leghorn hen. Asian-Aust. J Anim Sci. 1989;2:67-75.

34. Chen W, Zhao F, Tian ZM, Zhang HX, Ruan D, Li Y, et al. Dietary calcium deficiency in laying ducks impairs eggshell quality by suppressing shell biomineralization. J Exp Biol. 2015;218:3336-43.

35. Dean WF, Scott ML, Young RJ, Ash WJ. Calcium requirement of ducklings. Poult Sci. 1967:46:1496-9.

36. Lin IM, Shen TF. Studies on duck nutrition. II. Calcium and phosphorus requirements of mule ducklings. Poult Sci. 1979;58:124-30.

37. Xia WG, Zhang HX, Lin YC, Zheng CT. Evaluation of dietary calcium requirements for laying Longyan shelducks. Poult Sci. 2015;94:2932-7.

38. Xie M, Wang SX, Hou SS, Huang W. Interaction between dietary calcium and non-phytate phosphorus on growth performance and bone ash in early white Pekin ducklings. Anim Feed Sci Technol. 2009;151:161-6.

39. Xie M, Wang SX, Hou SS, Huang W. Calcium and phosphorus requirements of Pekin ducks from 3-6 weeks of age. Chin J Anim Nutr. 2009; 21; 25-30. (Chinese).

40. Leeson S. Copper metabolism and dietary needs. World's Poult Sci J. 2009; 65:353-66.

41. Lim HS, Paik IK. Effects of dietary supplementation of copper chelates in the form of methionine, chitosan and yeast in laying hens. Asian-Aust J Anim Sci. 2006:19:1174-9.

42. Güçl BK, Kara K, Beyaz L, Uyanik F, Eren M, Atasever A. Influence of dietary copper proteinate on performance, selected biochemical parameters, lipid peroxidation, liver, and egg copper content in laying hens. Biol Trace Elem Res. 2008:125:160-9.

43. Pekel AY, Alp M. Effects of different dietary copper sources on laying hen performance and egg yolk cholesterol. J Appl Poult Res, 2011:20: 506-13.

44. Jegede AV, Oduguwa OO, Oso AO, Fafiolu AO, Idowu OMO, Nollet L. Growth performance, blood characteristics and plasma lipids of growing pullet fed dietary concentrations of organic and inorganic copper sources. Livest Sci. 2012;145:298-302

45. Wang C, Wang MQ, Ye SS, Tao WJ, Effects DYJ. Of copper-loaded chitosan nanoparticles on growth and immunity in broilers. Poult Sci. 2011;90:2223-8.

46. Mroczek-Sosnowska N, Łukasiewicz M, Wnuk A, Sawosz E, Niemiec J, Skot $A$, et al. In ovo administration of copper nanoparticles and copper sulfate positively influences chicken performance. J Sci Food Agr. 2016;96:3058-62.

47. Attia YA, Qota EM, Zeweil HS, Bovera F. Abd al-Hamid AE, Sahledom MD. Effect of different dietary concentrations of inorganic and organic copper on growth performance and lipid metabolism of white Pekin male ducks. Br Poult Sci. 2012;53:77-88. 
48. Fouad AM, Li Y, Chen W, Ruan D, Wang S, Xia WG, et al. Effects of dietary copper supplementation on laying performance, egg quality and plasma cholesterol fractions in laying ducks. Pak J Nutr. 2016;15: 878-82.

49. Attia YA, Abdalah AA, Zeweil HS, Bovera F, El-Din AT, Araft MA. Effect of inorganic or organic copper additions on reproductive performance, lipid metabolism and morphology of organs of dual-purpose breeding hens. Arch Geflugelk. 2011;3:169-78.

50. Kidd MT, Ferket PR, Qureshi MA. Zinc metabolism with special reference to its role in immunity. World's Poult Sci J. 1996;52:309-24.

51. Amen $\mathrm{MH}, \mathrm{Al}$-Daraji $\mathrm{HJ}$. Influence of dietary supplementation with zinc on sex hormones concentrations of broiler breeder chickens. Pak J Nutr. 2011;10:1089-93.

52. Gao J, Lv Z, Li C, Yue Y, Zhao X, Wang F, et al. Maternal zinc supplementation enhanced skeletal muscle development through increasing protein synthesis and inhibiting protein degradation of their offspring. Biol Trace Elem Res. 2014;162:309-16.

53. Liu ZH, Lu L, Wang RL, Lei HL, Li SF, Zhang LY, et al. Effects of supplemental zinc source and level on antioxidant ability and fat metabolism-related enzymes of broilers. Poult Sci. 2011;94:2686-94.

54. Blamberg DL, Blackwood UB, Supplee WC, Combs GF. Effect of zinc deficiency in hens on hatchability and embryonic development. Proc Soc Exp Biol Med. 1960;104:217-20.

55. Schuster $\mathrm{NH}$, Hindmarsh M. Plasma alkaline phosphatase as a screening test for low zinc status in broiler hybrid chickens affected with 'clubbed down'. Austr Vet J. 1980;56:499-501.

56. Cui $H, X i$, Junliang D, Debing L, Guang Y. Pathology of lymphoid organs in chickens fed a diet deficient in zinc. Avian Path. 2004:33:519-24.

57. Zhang L, Wang YX, Xiao X, Wang JS, Wang Q, Li KX, et al. Effects of zinc Glycinate on productive and reproductive performance, zinc concentration and antioxidant status in broiler breeders. Biol Trace Elem Res. 2017; https://doi.org/10.1007/s12011-016-0928-4.

58. Zhu Y, Liao X, Lu L, Li W, Zhang L, Ji C, et al. Maternal dietary zinc supplementation enhances the epigenetic-activated antioxidant ability of chick embryos from maternal normal and high temperatures. Oncotarget. 2017;8(12):19814-24. https://doi.org/10.18632/oncotarget.15057.

59. Sunder GS, Panda AK, Gopinath NCS, Rao SR, Raju MVLN, Reddy MR, et al. Effects of higher levels of zinc supplementation on performance, mineral availability, and immune competence in broiler chickens. J Appl Poult Res. 2008;17:79-86.

60. Jarosz $Ł$, Marek A, Grądzki Z, Kwiecień M, Kalinowski M. The effect of feed supplementation with zinc chelate and zinc sulphate on selected humoral and cell-mediated immune parameters and cytokine concentration in broiler chickens. Res Vet Sci. 2017;112:59-65.

61. Kwiecień M, Winiarska-Mieczan A, Milczarek A, Tomaszewska E, Matras J. Effects of zinc glycine chelate on growth performance, carcass characteristics, bone quality, and mineral content in bone of broiler chicken. Livest Sci. 2016;191:43-50.

62. Attia YA, Al-Hamid AA, Zeweil HS, Qota EM, Bovera F, Monastra G, et al. Effect of dietary amounts of inorganic and organic zinc on productive and physiological traits of white Pekin ducks. Anim. 2013;7:895-900.

63. Chen W, Wang S, Zhang HX, Ruan D, Xia WG, Cui YY, et al. Optimization of dietary zinc for egg production and antioxidant capacity in Chinese egg-laying ducks fed a diet based on corn-wheat bran and soybean meal. Poult Sci. 2017;96(7):2336-43. https://doi.org/10. 3382/ps/pex032

64. Olgun O. Manganese in poultry nutrition and its effect on performance and eggshell quality. World's Poult Sci J. 2017;73:45-56.

65. Lu L, Ji C, Luo XG, Liu B, Yu SX. The effect of supplemental manganese in broiler diets on abdominal fat deposition and meat quality. Anim Feed Sci Technol. 2006;129:49-59.

66. Lu L, Luo XG, Ji C, Liu B, Effect YSX. Of manganese supplementation and source on carcass traits, meat quality and lipid oxidation in broilers. J Anim Sci. 2007:85:812-22.

67. Liu XF, Zhang LM, Zhang Z, Liu N, SW X, Lin HJ. Manganese-induced effects on testicular trace element levels and crucial hormonal parameters of Hyline cocks. Biol Trace Elem Res. 2013;151:217-24.

68. Xie J, Tian C, Zhu Y, Zhang L, Lu L, Luo X. Effects of inorganic and organic manganese supplementation on gonadotropin-releasing hormone-I and follicle-stimulating hormone expression and reproductive performance of broiler breeder hens. Poult Sci. 2014;93:959-69.
69. Liu X, Li Z, Han C, Zhang Z, Effects XS. Of dietary manganese on Cu, Fe, Zn, ca, se, IL-1 $\beta$, and IL-2 changes of immune organs in cocks. Biol Trace Elem Res. 2012;148:336-44.

70. Li S, Lu L, Hao S, Wang Y, Zhang L, Liu S, et al. Dietary manganese modulates expression of the manganese-containing superoxide dismutase gene in chickens. J Nutr. 2011;141:189-94.

71. Wang J, Wang ZY, Wang ZJ, Liu R, Liu SQ, Wang L. Effects of manganese deficiency on chondrocyte development in tibia growth plate of arbor acres chicks. J Bone Miner Metab. 2015;33:23-9.

72. Xiao JF, Zhang YN, SG W, Zhang HJ, Yue HY, Qi GH. Manganese supplementation enhances the synthesis of glycosaminoglycan in eggshell membrane: a strategy to improve eggshell quality in laying hens. Poult Sci. 2014;93:380-8.

73. Zhu YW, Lu L, Li WX, Zhang LY, Ji C, Lin X, et al. Effects of maternal dietary manganese and incubation temperature on hatchability, antioxidant status, and expression of heat shock proteins in chick embryos. J Anim Sci. 2015:93:5725-34.

74. Parker HE, Andrews FN, Carrick CW, Creek RD, Hauge SM. Effect of manganese on bone formation studied with radioactive isotopes. Poult Sci. 1955;34:1154-8

75. Leach RM, Gross JR. The effect of manganese deficiency upon the ultrastructure of the eggshell. Poult Sci. 1983;62:499-504.

76. Fouad AM, Li Y, Chen W, Ruan D, Wang S, Xia WG, et al. Effects of dietary manganese supplementation on laying performance, egg quality and antioxidant status in laying ducks. Asian J Anim Vet Adv. 2016;11:570-5.

77. Ma X, Liao X, Lu L, Li S, Zhang L, Luo X. Determination of dietary iron requirements by full expression of iron-containing enzymes in various tissues of broilers. J Nutr. 2016;146:2267-73.

78. Ma XY, Liu SB, Lu L, Li SF, Xie JJ, Zhang LY, et al. Relative bioavailability of iron proteinate for broilers fed a casein-dextrose diet. Poult Sci. 2014;93:556-63.

79. Bess F, Vieira SL, Favero A, Cruz RA, Nascimento PC. Dietary iron effects on broiler breeder performance and egg iron contents. Anim Feed Sci Technol. 2012;178:67-73.

80. Mohammadi H, Farzinpour A, Vaziry A. Reproductive performance of breeder quails fed diets supplemented with L-cysteine-coated iron oxide nanoparticles. Reprod Domest Anim. 2017:52:298-304.

81. Sun J, Liu D, Shi R. Supplemental dietary iron glycine modifies growth, immune function, and antioxidant enzyme activities in broiler chickens. Livest Sci. 2015;176:129-34.

82. Jarosz Ł, Kwiecień M, Marek A, Grądzki Z, Winiarska-Mieczan A, Kalinowski M, et al. Effects of feed supplementation with glycine chelate and iron sulfate on selected parameters of cell-mediated immune response in broiler chickens. Res Vet Sci. 2016:107:68-74.

83. Xia W, Lin YC, Zheng $C T$, Chen W, Ruan D, Wang S, et al. Effects of Dietary Iron Level on Laying Performance, Egg Quality, Liver and Blood Indices of Shanma Laying Duck. Chin J Anim Nutr. 2016. 28:71-78. (Chinese).

84. Jianhua H, Ohtsuka A, Hayashi K. Selenium influences growth via thyroid hormone status in broiler chickens. Br J Nutr. 2000;84:727-32.

85. Peng $X$, Cui H, Fang J, Zuo Z, Deng J, Pan K, et al. Low selenium diet alters cell cycle phase, apoptotic population and modifies oxidative stress markers of spleens in broilers. Biol Trace Elem Res. 2012;148:182-6.

86. Peng X, Cui Y, Cui W, Deng J, Cui H, Yang F. The cell cycle arrest and apoptosis of bursa of Fabricius induced by low selenium in chickens. Biol Trace Elem Res. 2011;139:32-40.

87. Peng X, Cui H, Yuan J, Cui W, Fang J, Zuo Z, et al. Low-selenium diet induces cell cycle arrest of thymocytes and alters serum IL-2 content in chickens. Biol Trace Elem Res. 2011;144:688-94.

88. Sun D, Li C, Gao J, Li S, Wang H. Effects of selenium deficiency on principal indexes of chicken kidney function. Biol Trace Elem Res. 2015:164:58-63.

89. JX X, Cao CY, Sun YC, Wang LL, Li N, SW X, et al. Effects on liver hydrogen peroxide metabolism induced by dietary selenium deficiency or excess in chickens. Biol Trace Elem Res. 2014;159:174-82.

90. Avanzo JL, de Mendonça Junior CX, de Cerqueira Cesar M. Role of antioxidant systems in induced nutritional pancreatic atrophy in chicken. Comp Biochem Physiol B Biochem Mol Biol. 2002;131:815-23.

91. Latshaw JD, Ort JF, Diesem CD. The selenium requirements of the hen and effects of a deficiency. Poult Sci. 1977;56:1876-81.

92. Thompson JN, Scott ML. Impaired lipid and vitamin E absorption related to atrophy of the pancreas in selenium-deficient chicks. J Nutr. 1970;100:797-809. 
93. Rajashree K, Muthukumar T, Karthikeyan N. Comparative study of the effects of organic selenium on hen performance and productivity of broiler breeders. Br Poult Sci. 2014;55:367-74.

94. Zhang L, Wang YX, Zhou Y, Zheng L, Zhan XA, Different PQH. Sources of maternal selenium affect selenium retention, antioxidant status, and meat quality of 56-day-old offspring of broiler breeders. Poult Sci. 2014;93:2210-9.

95. Perić L, Milošević N, Žikić D, Kanački Z, Džinić N, Nollet L, et al. Effect of selenium sources on performance and meat characteristics of broiler chickens. J Appl Poult Res. 2009;18:403-9.

96. Cai SJ, Wu CX, Gong LM, Song T, Wu H, Zhang LY. Effects of nanoselenium on performance, meat quality, immune function, oxidation resistance, and tissue selenium content in broilers. Poult Sci. 2012;91: 2532-9.

97. Biswas A, Mohan J, Mandal AB, Lal N. Semen characteristics and biochemical composition of cloacal foam of male Japanese quails (Coturnix coturnix Japonica) fed diet incorporated with selenium. J Anim Phys Anim Nutr. 2017;101:229-35.

98. Baltić MŽ, Starčević MD, Bašić M, Zenunović A, Ivanović J, Marković R, et al. Effects of dietary selenium-yeast concentrations on growth performance and carcass composition of ducks. Anim Prod Sci. 2017; https://doi.org/10.1071/AN16126.

99. Chen W, Zhang HX, Wang S, Ruan D, Xie XZ, DQ Y, et al. Estimation of dietary selenium requirement for Chinese egg-laying ducks. Anim Prod Sci. 2015;55:1056-63.

100. Wang Z, Studies on the Requirement of Selenium and its Mechanism of Action for Peking Ducks between $0 \mathrm{~W}$ and $3 \mathrm{~W}$ of Age. MS Thesis. Guangdong Ocean university. China: Guangdong; 2006.

101. Schexnailder R, Griffith M. Liver fat and egg production of laying hens as influenced by choline and other nutrients. Poult Sci. 1973;52: 1188-94.

102. Simon J. Choline, betaine and methionine interactions in chickens, pigs and fish (including crustaceans). World's Poult Sci J. 1999;55:353-74.

103. Wen ZG, Tang J, Hou SS, Guo YM, Huang W, Xie M. Choline requirements of white Pekin ducks from hatch to 21 days of age. Poult Sci. 2014;93:3091-6.

104. Wen ZG, Hou SS, Tang J, Feng YL, Huang W, Guo YM, et al. Choline requirements of male white Pekin ducks from 21 to $42 \mathrm{~d}$ of age. Br Poult Sci. 2014:55:548-52.

105. Lien TF, Jan DF. The lipogenic capacity of hepatocytes and lipolytic rate of adipocytes in Tsaiya ducks during growing and laying periods. Asian-Aust J Anim Sci. 1999:1258-62.

106. Ma W, Wang S, Shen D, Lin C, Xu H, Luo J, et al. Effects of choline level in diet on lipid metabolism in Shaoxing ducks during the initial egg-laying period. Acta Vet et Zootechnica Sinica. 2014;45:233-42.

107. Ashoori M, Saedisomeolia A. Riboflavin (vitamin B 2) and oxidative stress: a review. Br J Nutr. 2014;111:1985-91.

108. Ruiz N, Harms RH. Riboflavin requirement of broiler fed acorn soybean diet. Poult Sci. 1988;67:794-9.

109. Olkowski AA, Classen HL. The study of riboflavin requirements in broiler chickens. Int J Vitam Nutr Res. 1998;68:316-27.

110. Tang J, Xie M, Yang J, Wen ZG, Zhu YW, Huang W, et al. Riboflavin requirements of white Pekin ducks from hatch to $21 \mathrm{~d}$ of age. Br Poult Sci. 2013;54:407-11.

111. Tang J, Wen ZG, Guo ZB, Huang W, Guo YM, Xie M, et al. Dietary riboflavin supplementation improve the growth performance and antioxidant status of starter white Pekin ducks fed a corn-soybean meal diets. Livest Sci. 2014;170:131-6.

112. Tang J, Hu J, Wen ZG, Jiang Y, AL-Kateb H, Huang W, et al. Effects of riboflavin supplementation on growth performance, carcass traits, and riboflavin status of growing male white Pekin ducks. Anim Feed Sci Technol. 2015;209:274-9.

113. Squires MW, Naber EC. Vitamin profiles of eggs as indicators of nutritional status in the laying hen: riboflavin study. Poult Sci. 1993;72: 483-94.

114. Arijeniwa A, Ikhimioya I, Bamidele OK, Ogunmodede BK. Riboflavin requirement of breeding hens in a humid tropical environment. J Appl Anim Res. 1996;10:163-6

115. Wang $S$, Chen W, Ruan D,Wang L, Zheng CT, Lin YC. Effects of Dietary Riboflavin Level on Laying Performance, Egg Quality, Blood Biochemical and Antioxidant Parameters of Laying Ducks in Cage. Anim Nutr. 2014; 26:32843290. (Chinese).
116. Weber GM. Improvement of flock productivity through supply of vitamins for higher laying performance and better egg quality. World's Poult Sci J. 2009;65:443-57.

117. Watkins BA, Kratzer FH. Dietary biotin effects on polyunsaturated fatty acids in chick tissue lipids and prostaglandin E2 levels in freeze-clamped hearts. Poult Sci. 1987;66:1818-28.

118. Whitehead CC, Pearson RA, Herron KM. Biotin requirements of broiler breeders fed diets of different protein content and effect of insufficient biotin on the viability of progeny. Br Poult Sci. 1985;26:73-82.

119. Zhu YW, Xie M, Huang W, Yang L, Hou SS. Effects of biotin on growth performance and foot pad dermatitis of starter white Pekin ducklings. Br Poult Sci. 2012;53:646-50.

120. Robel EJ. The value of supplemental biotin for increasing hatchability of turkey eggs. Poult Sci. 1991;70:1716-22.

121. Daryabari H, Akhlaghi A, Zamiri MJ, Mianji GR, Pirsaraei ZA, Deldar $H$, et al. Reproductive performance and oviductal expression of avidin and avidin-related protein-2 in young and old broiler breeder hens orally exposed to supplementary biotin. Poult Sci. 2014;93:2289-95.

122. Daryabari H, Akhlaghi A, Zamiri MJ, Pirsaraei ZA, Mianji GR, Deldar H, et al. Oral administration of supplementary biotin differentially influences the fertility rate and oviductal expression of avidin and avidin-related protein-2 in low-and high-fertility broiler line hens. Poult Sci. 2015;94:289-95.

123. Sun ZW, Fan $Q H$, Wang XX, Guo YM, Wang HJ, Dong X. High dietary biotin levels affect the footpad and hock health of broiler chickens reared at different stocking densities and litter conditions. J Anim phys Anim Nutr. 2017;101(3):521-30. https://doi.org/10.1111/jpn.12465.

124. Taylor LW. The effect of folic acid on egg production and hatchability. Poult Sci. 1947;26:372-6.

125. Pesti GM, Rowland GN, Ryu KS. Folate deficiency in chicks fed diets containing practical ingredients. Poult Sci. 1991;70:600-4.

126. Jing M, Munyaka PM, Tactacan GB, Rodriguez-Lecompte JC, House JD. Performance, serum biochemical responses, and gene expression of intestinal folate transporters of young and older laying hens in response to dietary folic acid supplementation and challenge with Escherichia coli lipopolysaccharide. Poult Sci. 2014;93:122-31.

127. Sahin K, Onderci M, Sahin N, Gursu MF, Kucuk O. Dietary vitamin C and folic acid supplementation ameliorates the detrimental effects of heat stress in Japanese quail. J Nutr. 2003;133:1882-6.

128. Dickson TM, Tactacan GB, Hebert K, Guenter W, House JD. Optimization of folate deposition in eggs through dietary supplementation of folic acid over the entire production cycle of Hy-line W36, Hy-line W98, and CV20 laying hens. J Appl Poult Res. 2010;19:80-91.

129. Li S, Zhi L, Liu Y, Shen J, Liu L, Yao J, et al. Effect of in ovo feeding of folic acid on the folate metabolism, immune function and epigenetic modification of immune effector molecules of broiler. Br J Nutr. 2016;115:411-21.

130. Liu Y, Zhi L, Shen J, Li S, Yao J, Yang X. Effect of in ovo folic acid injection on hepatic IGF2 expression and embryo growth of broilers. J Anim Sci Biotechnol. 2016;7:40.

131. Xia W, Wang L, Chen W, Ruan D, Wang S, Fouad AM, et al. Effects of Dietary Folic Acid Supplemental Level on Laying Performance, Egg Quality, Reproductive Organ and Plasma Reproductive Hormone Indices of Shanma Laying Ducks. Chin J Anim Nutr. 2016; 28:2024-2031. (Chinese).

132. Attar MW, Daghir NJ, Asmar J. Influence of vitamin B6 deficiency on certain serum components in mature female chickens. Poult Sci. 1967;46:838-43.

133. Weiss FG, Scott ML. Influence of vitamin B-6 upon reproduction and upon plasma and egg cholesterol in chickens. J Nutr. 1979;109:1010-7.

134. Blalock TL, Thaxton JP, Garlich JD. Humoral immunity in chicks experiencing marginal vitamin B-6 deficiency. J Nutr. 1984;114:312-22.

135. Waldenstedt L. Nutritional factors of importance for optimal leg health in broilers: a review. Anim Feed Sci Technol. 2006;126:291-307.

136. Robel EJ, Christensen VL. Increasing hatchability of turkey eggs by injecting eggs with pyridoxine. Br Poult Sci. 1991;32:509-13.

137. Kucuk O, Kahraman A, Kurt I, Yildiz N, Onmaz ACA. Combination of zinc and pyridoxine supplementation to the diet of laying hens improves performance and egg quality. Biol Trace Elem Res. 2008;126:165-75.

138. Xie M, Tang J, Wen Z, Huang W, Hou S. Effects of pyridoxine on growth performance and plasma aminotransferases and homocysteine of white Pekin ducks. Asian-Aust. J Anim Sci. 2014;27:1744-8.

139. Park IK, Marquardt RR. Effect of niacin deficiency on the thermal stability of NAD-and NADP-dependent dehydrogenases in liver and pectoral muscle of Japanese quail. Int J Biochem Cell Biol. 1996;28:1169-77. 
140. Childs GR, Carrick CW, Hauge SM. The niacin requirement of young chickens. Poult Sci. 1952;31:551-8

141. Park IK, Marquardt RR. Effects of niacin deficiency on pyridine nucleotide levels and enzyme activities in various organs of young growing quail. J Nutr. 1982;112:863-73.

142. Adams RL, Carrick CWA. Study of the niacin requirement of the laying hen Poult Sci. 1967:46:712-8.

143. Jiang RR, Zhao GP, Chen JL, Zheng MQ, Zhao JP, Li P, et al. Effect of dietary supplemental nicotinic acid on growth performance, carcass characteristics and meat quality in three genotypes of chicken. J Anim phys Anim Nutr. 2011;95:137-45

144. Gungor T, Yigit AA, Basalan M. The effects of supplemental niacin in laying hen diet on performance and egg quality characteristics. Rev Med Vet. 2003;154:371-4.

145. Xie M, Han XF, Huang W, Hou SS. Effects of niacin status on tryptophan requirements of starter white Pekin ducks. Livest Sci. 2014;159:75-8.

146. Wang S, Zhang X, Ruan D, Chen W, Lin YC. Effects of Dietary Niacin Supplemental Level on Laying Performance, Egg Quality and Plasma Biochemical Indexes of Ducks during the Early Laying Period. Chin J Anim Nutr. 2014; 26:1807-1813. (Chinese)

147. Polin D, Ott WH, Wynosky ER, Porter CC. Estimation of thiamine requirement for optimum hatchability from the relationship between dietary and yolk levels of the vitamin. Poult Sci. 1963:42:925-8.

148. Sullivan TW, Heil HM, Armintrout ME. Dietary thiamine and pyridoxine requirements of young turkeys. Poult Sci. 1967:46:1560-4.

149. Charles OW, Roland DA, Edwards HM. Thiamine deficiency identification and treatment in commercial turkeys and coturnix quail. Poult Sci. 1972;51: 419-23.

150. Gries CL, Scott ML. The pathology of thiamin, riboflavin, pantothenic acid and niacin deficiencies in the chick. J Nutr. 1972;102:1269-85.

151. Ogunmodede BK, Vitamin A. Requirement of broiler chicks in Nigeria. Poult Sci. 1981;60:2622-7.

152. Friedman A, Sklan D, Impaired T. Lymphocyte immune response in vitamin a depleted rats and chicks. Br J Nutr. 1989:62:439-49.

153. Squires MW, Naber EC. Vitamin profiles of eggs as indicators of nutritional status in the laying hen: vitamin a study. Poult Sci. 1993:72:154-64.

154. Maden M, Gale E, Kostetskii I, Zile M. Vitamin A-deficient quail embryos have half a hindbrain and other neural defects. Curr Biol. 1996:6:417-26.

155. Yuan J, Roshdy AR, Guo Y, Wang Y, Guo S. Effect of dietary vitamin a on reproductive performance and immune response of broiler breeders. PLoS One. 2014;9:e105677

156. Fan X, Liu S, Liu G, Zhao J, Jiao H, Wang X, et al. Vitamin a deficiency impairs mucin expression and suppresses the mucosal immune function of the respiratory tract in chicks. PLoS One. 2015;10:e0139131.

157. Chen F, Jiang Z, Jiang S, Li L, Lin X, Gou Z, et al. Dietary vitamin a supplementation improved reproductive performance by regulating ovarian expression of hormone receptors, caspase- 3 and Fas in broiler breeders. Poult Sci. 2016;95:30-40.

158. Wei L, Hou S, Huang W, Xie M, Zhang T, Liu F. Effects of vitamin A on performance and intestinal development of Beijing ducks from 0-3 weeks of age. Chin J Anim Nutr. 2009;21:462-467. (Chinese).

159. Wang S, Zhang X,Chen W, Ruan D,Xia W, Li Y, et al. Effect of Different Concentrations of Vitamin A on Production Performance,Egg Quality, and Antioxidant Indicators in Ducks. Chin Poult. 2016;38:1004-6364. (Chinese).

160. Stadelman WJ, Boucher RV, Callenbach EW. The effect of vitamin D in the turkey breeder ration on egg production and hatchability and on growth and calcification of the poults. Poult Sci. 1950;29:146-52.

161. Aslam SM, Garlich JD, Qureshi MA, Vitamin D. Deficiency alters the immune responses of broiler chicks. Poult Sci. 1998:77:842-9.

162. Han JC, Yang XD, Zhang T, Li H, Li WL, Zhang ZY, et al. Effects of $1 a$ hydroxycholecalciferol on growth performance, parameters of tibia and plasma, meat quality, and type IIb sodium phosphate cotransporter gene expression of one-to twenty-one-day-old broilers. Poult Sci. 2009;88:323-9.

163. Han JC, Wang YL, HX Q, Liang F, Zhang JL, Shi CX, et al. One alphahydroxycholecalciferol improves growth performance, tibia quality, and meat color of broilers fed calcium-and phosphorus-deficient diets AsianAust. J Anim Sci. 2011;25:267-71.

164. Vignale K, Greene ES, Caldas JV, England JA, Boonsinchai N, Sodsee P, et al. 25-hydroxycholecalciferol enhances male broiler breast meat yield through the mTOR pathway. J Nutr. 2015;145:855-63.
165. Chou SH, Chung TK, Effects YB. Of supplemental 25-hydroxycholecalciferol on growth performance, small intestinal morphology, and immune response of broiler chickens. Poult Sci. 2009;88:2333-41.

166. Shojadoost B, Behboudi S, Villanueva Al, Brisbin JT, Ashkar AA, Sharif S. Vitamin D3 modulates the function of chicken macrophages. Res Vet Sci. 2015;100:45-51.

167. Atencio A, Edwards HM, Pesti G. Effects of vitamin D3 dietary supplementation of broiler breeder hens on the performance and bone abnormalities of the progeny. Poult Sci. 2005;84:1058-68.

168. Wang S, Hou S, Xie M, Huang W, Yu J. Effects of different concentrations of vitamin D on growth performance, blood biochemistry and tibia parameters for White Pekin duclings. Chin J Animal Vet Sci. 2009;41:14141420. (Chinese).

169. Xie J, Wang A. Effects of dietary Vitamin D level on immune and antioxidant functions of Egg-type ducks. Chin J Anim Nutr. 2012:24:819. 1824. (Chinese).

170. Wang S, Lin C, Hang H, Ma X, Cen W, Dong R. Effects of different concentrations of vitamin $\mathrm{D}$ on performance, egg quality plasma and bone indicators in Longyan ducks during 16-18 weeks old. Nutr Fedstuffs. 2013; 46:22-26. (Chinese).

171. Chen TF. Effects of vitamin D3 supplementation on laying performance and eggshell quality of laying Tsaiya ducks. Asian-Aust. J Anim Sci. 2000;13:131-3.

172. Olson G, Matterson LD, Tlustohowicz J. Effect of vitamin E and antioxidants on fertility and hatchability as affected by unsaturated fatty acids. Poult Sci. 1962;41:675-7.

173. Chang WP, Hom JS, Dietert RR, Combs GF, Marsh JA. Effect of dietary vitamin E and selenium deficiency on chicken Splenocyte Proliferan and cell surface marker Expresssion. Immunopharm Immunot. 1994;16:203-23.

174. Bieri JG. Current aspects of vitamin a, vitamin $\mathrm{E}$, and selenium in poultry nutrition. World's Poult Sci J. 1960;16:245-58.

175. Sahin N, Sahin K, Onderci M, Karatepe M, Smith MO, Kucuk O. Effects of dietary lycopene and vitamin E on egg production, antioxidant status and cholesterol levels in Japanese quail. Asian-Aust. J Anim Sci. 2006;19:224-30.

176. Biswas A, Mohan J, Sastry KVH. Effect of vitamin E on production performance and egg quality traits in Indian native Kadaknath hen. AsianAust. J Anim Sci. 2010;23:396.

177. Biswas A, Mohan J, Sastry KVH. Effect of higher dietary vitamin E concentrations on physical and biochemical characteristics of semen in Kadaknath cockerels. Br Poult Sci. 2009;50:733-8.

178. Leshchinsky TV, Klasing KC. Relationship between the level of dietary vitamin E and the immune response of broiler chickens. Poult Sci. 2001:80:1590-9.

179. Cheng K, Niu Y, Zheng XC, Zhang H, Chen YP, Zhang M, et al. A comparison of natural (D-a-tocopherol) and synthetic (DL-a-tocopherol acetate) vitamin $E$ supplementation on the growth performance, meat quality and oxidative status of broilers. Asian-Aust. J Anim Sci. 2016;29:681-8

180. Chen TF, Hsu JC. Effects of n-3 polyunsaturated fatty acids-enriched diet supplemented with different levels of alpha-tocopherol on lipid metabolism in laying Tsaiya ducks. Asian-Aust. J Anim Sci. 2004;17:1562-9.

\section{Submit your next manuscript to BioMed Central and we will help you at every step:}

- We accept pre-submission inquiries

- Our selector tool helps you to find the most relevant journal

- We provide round the clock customer support

- Convenient online submission

- Thorough peer review

- Inclusion in PubMed and all major indexing services

- Maximum visibility for your research

Submit your manuscript at www.biomedcentral.com/submit 